\title{
Marble Quarry Waste Rock Piles and Evaluation of Their Reprocessing Potential for Lime and Cement Production (Marble Zone, Alentejo, Portugal)
}

\author{
Paulo Sá Caetano1, Tatiana Ribeiro², Carlos Costa ${ }^{3}$, and Daniel Vendas ${ }^{3}$ \\ ${ }^{1}$ FCT NOVA, GeoBioTec. Quinta da Torre, 2829-516 Caparica, Portugal \\ ${ }^{2}$ FCT NOVA, Quinta da Torre, 2829-516 Caparica, Portugal \\ ${ }^{3}$ Egiamb, Lda. Praça Quinta de São Francisco dos Matos, 4-E, 2825-049 Caparica, Portugal
}

Corresponding Author:

Paulo Sá Caetano

pcsc@fct.unl.pt

Received: 20 March 2020

Accepted: 30 April 2020

Published: 13 April 2020

Publishing services provided by

Knowledge E

(c) Paulo Sá Caetano et al. This article is distributed under the terms of the Creative Commons

Attribution License, which

permits unrestricted use and

redistribution provided that the

original author and source are

credited.

Selection and Peer-review under the responsibility of the RICON19 - REMINE International Conference Conference Committee.

\section{Abstract}

Approximately $80 \%$ to $90 \%$ of the total stone extracted by the ornamental stone industry in the Marble Zone (Alentejo, South Portugal) is wasted and discarded in the numerous quarry waste rock piles across the region. This enormous amount of marble waste, representing millions of tons of stone each year, mostly with an expected high chemical composition of calcium carbonate, has significant potential with regards to reprocessing and use in other industries. This study evaluates the potential viability of these marble waste piles for reprocessing. The methodological approach, designed in two phases, firstly selected potential sites and, secondly implemented a sampling plan to allow for the laboratory analyses. In the first phase, a total of 178 waste rock piles were identified, corresponding to an estimated $70 \mathrm{mn}$ tons of marble raw material. In the second phase, 30 selected piles were sampled and chemically analysed by calcimetry, XRF and flame emission spectrometry. The results show that 7 of the sampled piles present $\mathrm{CaCO}_{3}$ content above 97\%, and another 14 show contents between 95\% - 97\%. This indicates that the waste could be reprocessed to produce lime and/or cement (clay materials are found in the surrounding schist outcrops in the region). There is also the potential for aggregate production for civil engineering works.

Keywords: marble, waste reprocessing, lime production

\section{Introduction}

It isestimated that approximately $80 \%$ to $90 \%$ of the total stone extracted by the ornamental stone industry in the Marble Zone (Alentejo, South Portugal) is wasted and accumulated in the numerous waste rock piles of the region (Figure 1). This enormous amount of waste, corresponding to millions of tons of stone each year, is due to the combination of a variety of factors, such as: 
1. high fracturing degree of the rock masses, which prevents the production of blocks with adequate trade sizes;

2. aesthetic aspects (presence of weathering features from oxidations, smudges, veins, etc.), which devalue the stone, to the point of making it unsuitable for ornamental use.

From the mineralogical point of view, marble, just like sedimentary limestone, is almost exclusively composed of calcite, i.e., chemically it is $\mathrm{CaCO} 3$ (calcium carbonate). Calcium carbonate is a raw material for many industries, from the above-mentioned ornamental stone industry, to others, such as construction and building materials, like gravel and other aggregates, cement, lime, fillers for paints, animal feed, paper, water treatment, etc. Considering these several potential uses, this study aims to evaluate the feasibility of an industrial use of marble waste produced by the ornamental stone industry in Alentejo, namely for lime and cement production. To attain this purpose, the study presents the methodology followed for the characterization of these waste piles in order to assess the potential for the reprocessing of this raw material.

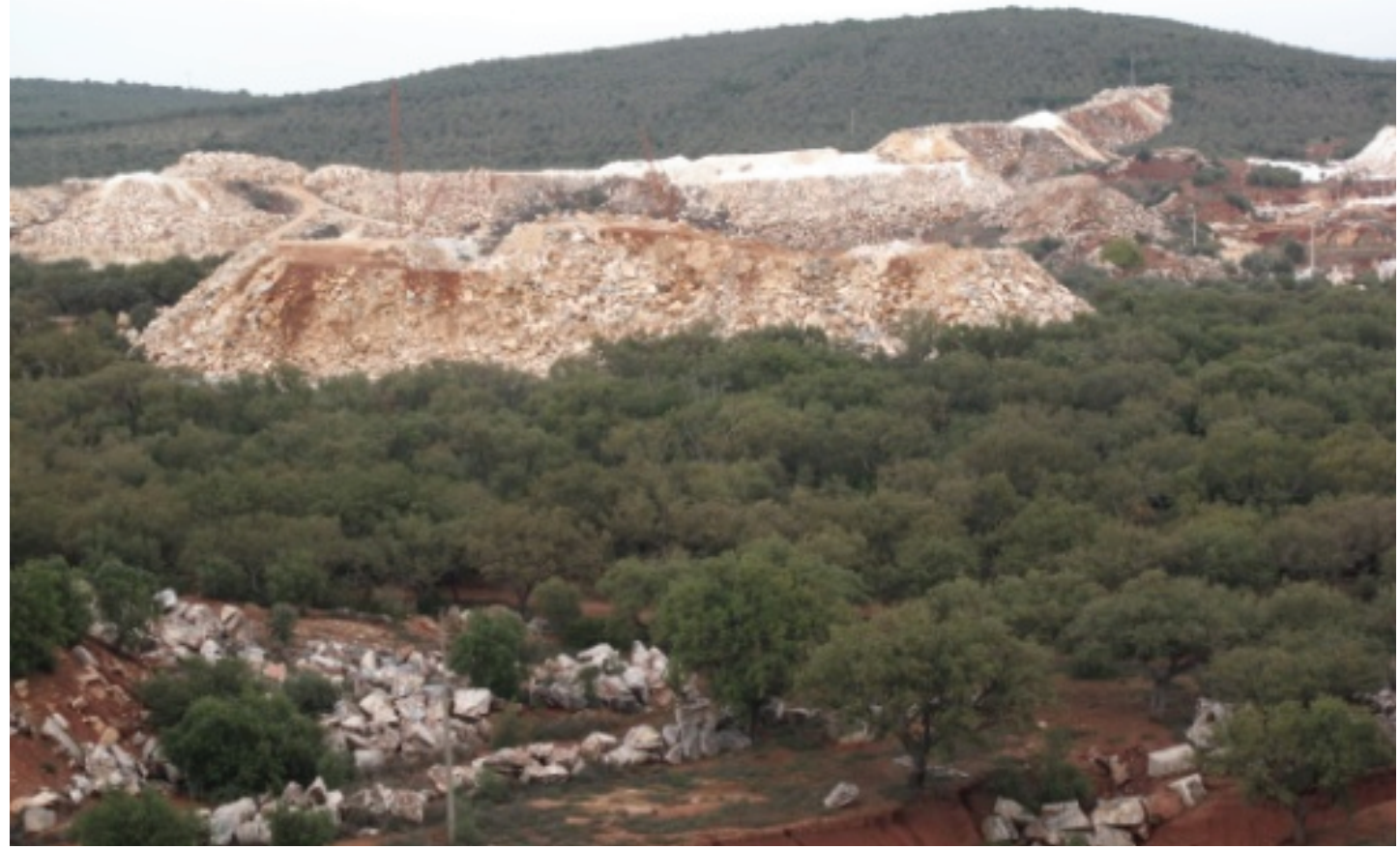

Figure 1: Waste rock piles produced by the ornamental stone industry in the Marble Zone (Alentejo, South Portugal). 


\section{Methodology}

The methodology followed in this study is basically structured in two phases:

1. Phase 1- site selection

2. Phase 2- preparation of a sampling plan in order to allow the necessary laboratory analysis to characterize the material.

Phase 1, by using Google Earth images and integration in a GIS database (ESRI ArcGIS 9.3), led to the identification of a total of 178 waste rock piles (Figure 2),corresponding to a calculated total volume of approximately 41.7 million $\mathrm{m}^{3}$ and a total tonnage of marble raw material close to 70 million tons (Table 1) [1-3].

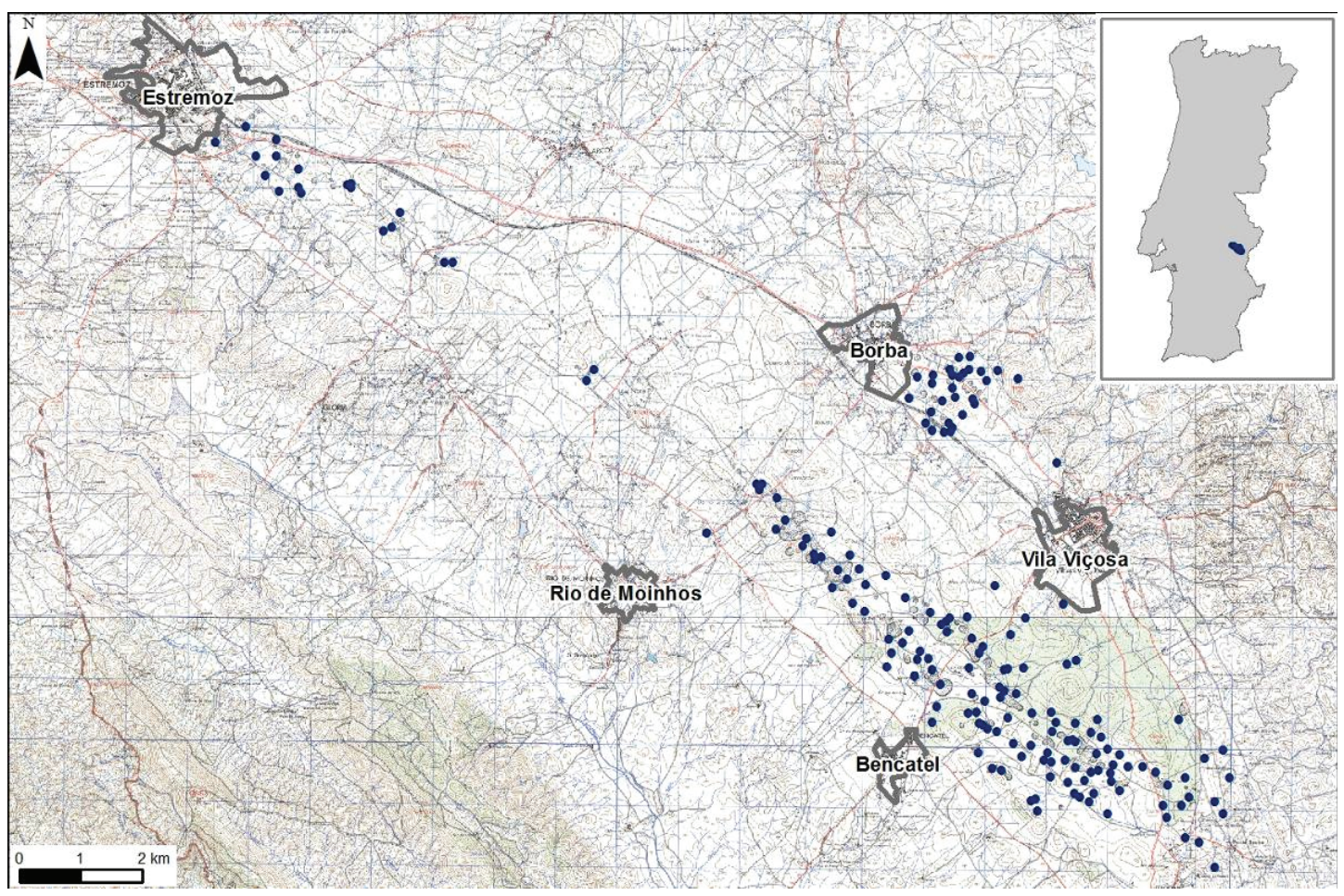

Figure 2: Location of the 178 waste rock piles (dots) identified using Google Earth images and integration in a GIS database.

TABLE 1: Total volume $\left(\mathrm{V}_{T}\right)$ and total solid volume $\left(\mathrm{V}_{S}\right)$, and respective total raw material volume $\left(\mathrm{V}_{\text {Raw }}\right)$ and tonnage $\left(Q_{\text {Raw } M}\right)$ calculated for the 178 waste rock piles.

Total Volume $\mathrm{V}_{T}$
$41.7^{*} 10^{6} \mathrm{~m}^{3}$

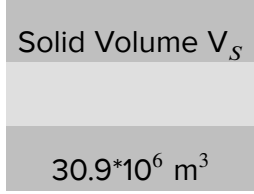

\begin{tabular}{|c|c|}
\hline \multicolumn{2}{|c|}{ Raw Material } \\
\hline Volume $\mathrm{V}_{\text {Raw }}$ & Quantity $\mathrm{Q}_{\text {Raw } M}$ \\
\hline $25.7^{*} 10^{6} \mathrm{~m}^{3}$ & $69.5^{*} 10^{6} \mathrm{t}$ \\
\hline
\end{tabular}

Based on the calculated quantity of raw material available to use, for example, in the production of lime, it is possible to estimate a total lifespan for each pile taking into 
consideration an average daily consumption of 300t, during 11 working months (335 days), as follows:

$$
\text { Lifespan }_{\text {years }}=Q_{\text {Raw M }} / 300 * 335
$$

Subsequently, Phase 2 delineated a sampling plan consisting of 30 selected waste piles geographically representative of the different marble types that are present in the Marble Zone region (Figure 3) and of the major extraction centres (Table 2): Cruz de Meninos (CM), Borba (B), Mouro-Vigária (MV), Lagoa (L) and Pardais (P). The total volume $\left(\mathrm{V}_{T}\right)$, solid volume $\left(\mathrm{V}_{S}\right)$, volume and quantity of raw material $\left(\mathrm{V}_{\text {Raw } M}\right.$ and $\left.\mathrm{Q}_{\text {Raw } M}\right)$ and the estimated lifespan (LS), according to equation (1), for each of the 30 selected piles are shown in Table 3.

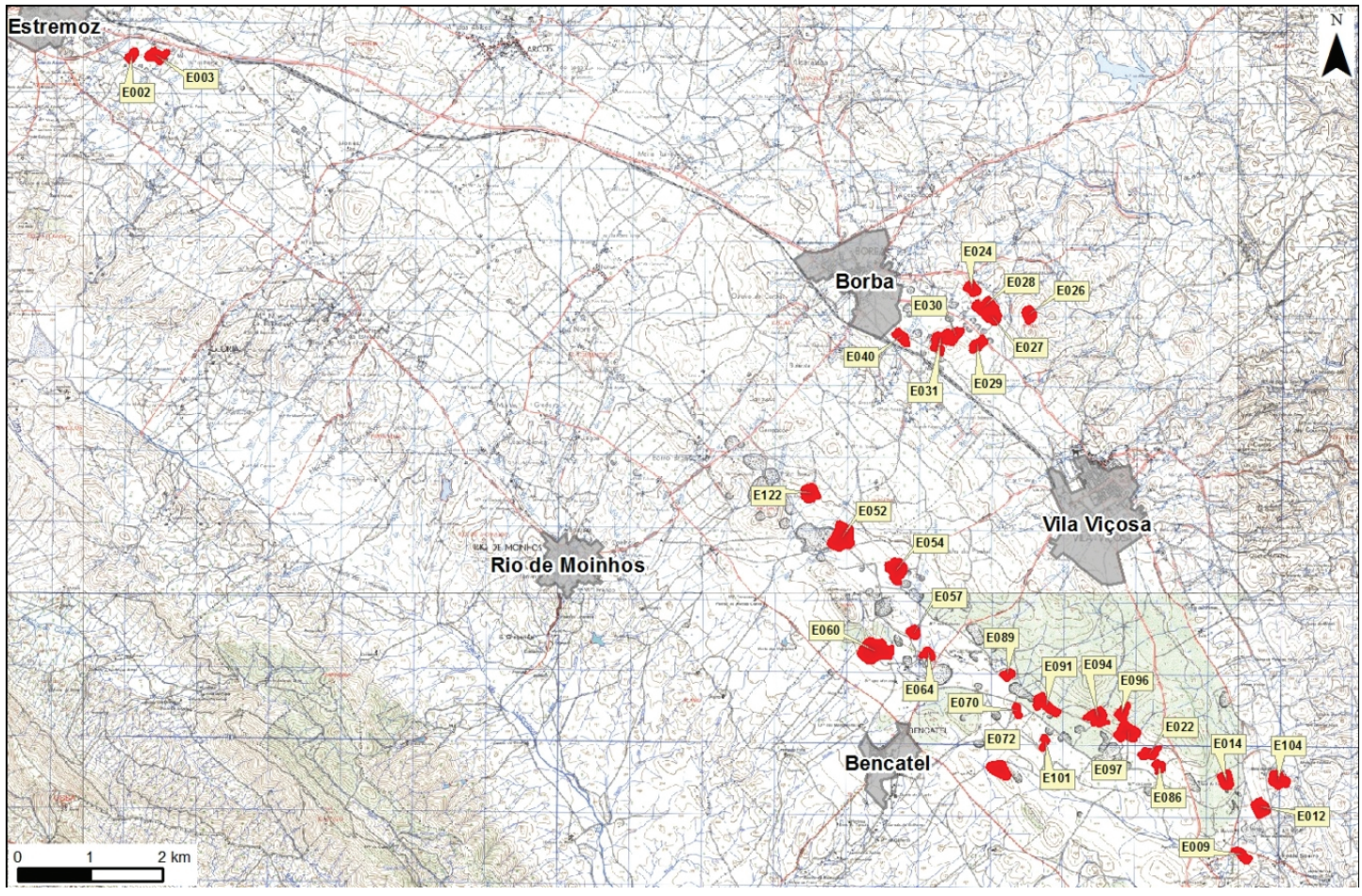

Figure 3: Location of the 30 selected waste rock piles (red shapes) representative of the different marble types that are present in the Marble Zone region.

TABLE 2: Number of waste rock piles selected from each sector and extraction centre in the Marble Zone.

Sector
Estremoz
Borba
Vila Viçosa

\begin{tabular}{c} 
Extraction Centre \\
Cruz de Meninos \\
Borba \\
\hline Mouro-Vigária \\
Lagoa \\
Pardais
\end{tabular}

$\mathrm{N}^{\circ}$ of sampled Piles
2
8
6
10
4


TABLE 3: List of the 30 selected waste rock piles ranked from the largest to smallest in quantity of raw material ( $\mathrm{R}$ - rank; EC - Extraction Centre; C - ID code)

\begin{tabular}{|c|c|c|c|c|c|c|c|}
\hline $\mathbf{R}$ & EC & C & $\begin{array}{c}\mathbf{V}_{T}\left(10^{3}\right. \\
\left.\mathbf{m}^{3}\right)\end{array}$ & $\begin{array}{c}\mathbf{V}_{S}\left(10^{3}\right. \\
\left.\mathbf{m}^{3}\right)\end{array}$ & $\begin{array}{c}\mathbf{V}_{\text {RawM }}\left(10^{3}\right. \\
\left.\mathbf{m}^{3}\right)\end{array}$ & $\begin{array}{l}\mathbf{Q}_{\text {Raw }} \\
\left(10^{3} t\right)\end{array}$ & LS (years) \\
\hline 1 & MV & E060 & 4066 & 3012 & 2510 & 6776 & 67 \\
\hline 2 & MV & E052 & 3066 & 2271 & 1892 & 5109 & 51 \\
\hline 3 & MV & E054 & 1646 & 1219 & 1016 & 2743 & 27 \\
\hline 4 & L & E097 & 1573 & 1165 & 971 & 2622 & 26 \\
\hline 5 & L & E072 & 1121 & 830 & 692 & 1868 & 19 \\
\hline 6 & $B$ & E028 & 1079 & 799 & 666 & 1798 & 18 \\
\hline 7 & L & E094 & 1009 & 747 & 623 & 1682 & 17 \\
\hline 8 & $P$ & E104 & 962 & 713 & 594 & 1604 & 16 \\
\hline 9 & MV & E122 & 962 & 713 & 594 & 1604 & 16 \\
\hline 10 & L & E091 & 914 & 677 & 564 & 1523 & 15 \\
\hline 11 & $B$ & E031 & 900 & 667 & 556 & 1501 & 15 \\
\hline 12 & $P$ & E012 & 823 & 610 & 508 & 1372 & 14 \\
\hline 13 & $\mathrm{CM}$ & E003 & 752 & 557 & 464 & 1253 & 12 \\
\hline 14 & $P$ & E014 & 693 & 513 & 428 & 1155 & 11 \\
\hline 15 & $B$ & E027 & 642 & 476 & 396 & 1070 & 10,6 \\
\hline 16 & L & E022 & 524 & 388 & 323 & 873 & 8,7 \\
\hline 17 & L & E096 & 485 & 359 & 299 & 809 & 8,0 \\
\hline 18 & $B$ & E024 & 467 & 346 & 288 & 779 & 7,7 \\
\hline 19 & B & E029 & 467 & 346 & 288 & 779 & 7,7 \\
\hline 20 & B & E026 & 461 & 341 & 285 & 768 & 7,6 \\
\hline 21 & $B$ & E030 & 453 & 336 & 280 & 755 & 7,5 \\
\hline 22 & B & E040 & 436 & 323 & 269 & 727 & 7,2 \\
\hline 23 & $\mathrm{P}$ & E009 & 351 & 260 & 216 & 585 & 5,8 \\
\hline 24 & MV & E057 & 303 & 224 & 187 & 504 & 5,0 \\
\hline 25 & MV & E064 & 271 & 201 & 167 & 452 & 4,5 \\
\hline 26 & $\mathrm{CM}$ & EOO2 & 257 & 190 & 158 & 428 & 4,3 \\
\hline 27 & L & E086 & 230 & 170 & 142 & 383 & 3,8 \\
\hline 28 & L & E089 & 205 & 151 & 126 & 341 & 3,4 \\
\hline 29 & L & E070 & 138 & 102 & 85 & 230 & 2,3 \\
\hline 30 & L & E101 & 129 & 95 & 79 & 214 & 2,1 \\
\hline
\end{tabular}




\section{Results}

All samples collected from the 30 waste rock piles were chemically analysed by calcimetry, XRF (X-ray fluorescence) and FAES (flame atomic emission spectrometry) in order to determine contents in major and minor elements: $\mathrm{Ca}, \mathrm{Mg}, \mathrm{Si}, \mathrm{Al}, \mathrm{Fe}, \mathrm{Na}, \mathrm{K}$, $\mathrm{Ti}, \mathrm{Mn}$; and also in TOC (total organic carbon), IR (insoluble residue) and LOI (loss on ignition).

A broad comparison of the obtained results in this study with those known of the 36 ornamental stone varieties produced in the region [4], does not show significant differences, thus corroborating that the major reason for all the stone waste being deposited in the waste piles is either due to insufficient block size in quarry extraction or to unsuitable aesthetic quality of the marble, rather than to poor raw material chemical characteristics, e.g. due to the presence of "contaminant" materials (such as schistous layers, basic igneous dykes, etc. that occur interspersed with the marble).

Table 4 shows the obtained results by grouping all samples from each extraction centre giving the respective mean and standard deviation (SD) values. Global mean, maximum, minimum and SD results for all 30 samples are also shown. According to literature review [e.g. $[5,6]]$, the major restraint for lime production, in terms of purity criteria of the raw material, mostly depends on the use that is intended. This means that, although there are reference values, essentially for carbonate content, they cannot be considered as mandatory limit values for the exclusion of a given sample. Still, generally, three ranges of carbonate content corresponding to the purity of the raw material can be considered: less than 95\%; between 95\% and 97\%; and greater than $97 \%$.

The chemical analyses of the sampled materials show that 7 piles present $\mathrm{CaCO}_{3}$ content above 97\% and another 14 show contents between 95\% - 97\%. This indicates a potential reprocessing use to produce lime and/or cement (clay materials are easily found in the surrounding schist outcrops in the region which, by the way, are source of local ceramic industry). The following figures (Figures 4 to 8 adapted from [3]) show the calcium carbonate content values obtained for the piles from each of the extraction centres analysed.

\section{Final Considerations}

This study has assessed the potential for reprocessing of the huge amount of waste produced by the ornamental stone industry in the Marble Zone of Alentejo, indicating as a feasible option the production of lime and/or cement although other uses may 


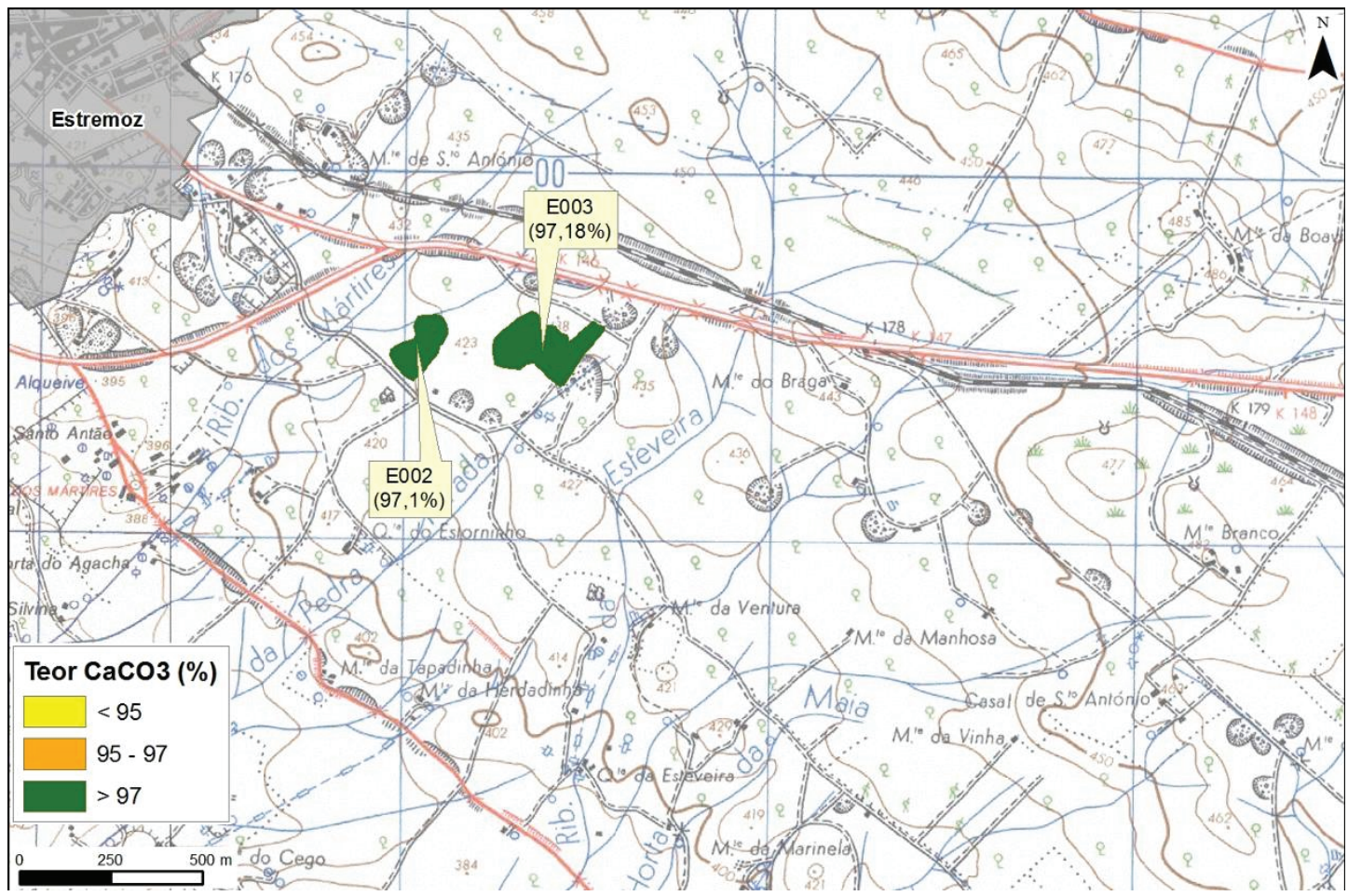

Figure 4: Calcium carbonate content for the waste rock piles from the Cruz de Meninos extraction centre.

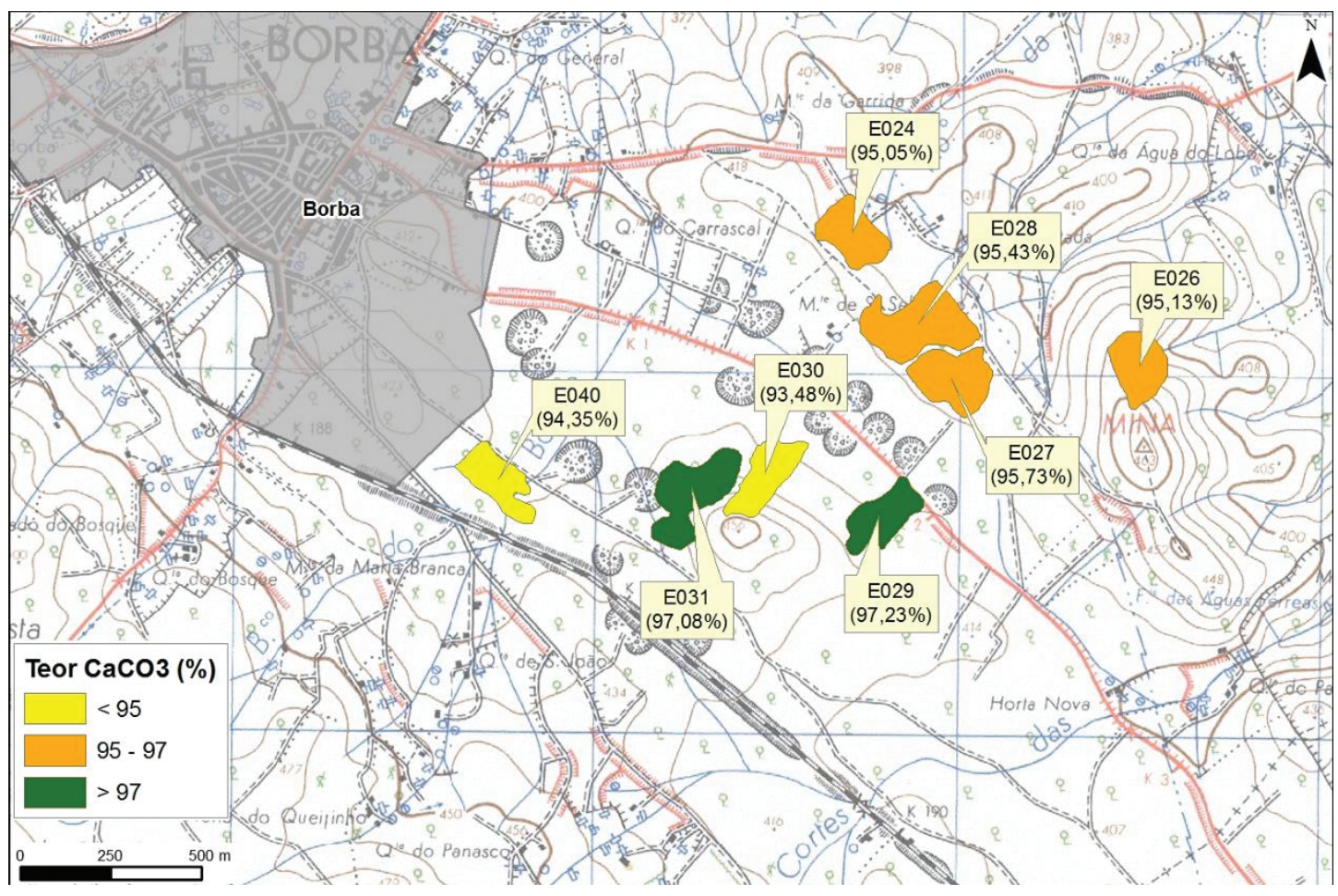

Figure 5: Calcium carbonate content for the waste rock piles from the Borba extraction centre.

point to aggregate production for civil engineering works, looking beyond the current «take and make waste» extractive model, towards a circular economy that focuses on positive society-wide benefits [7]. From the economic point of view, the main advantage 


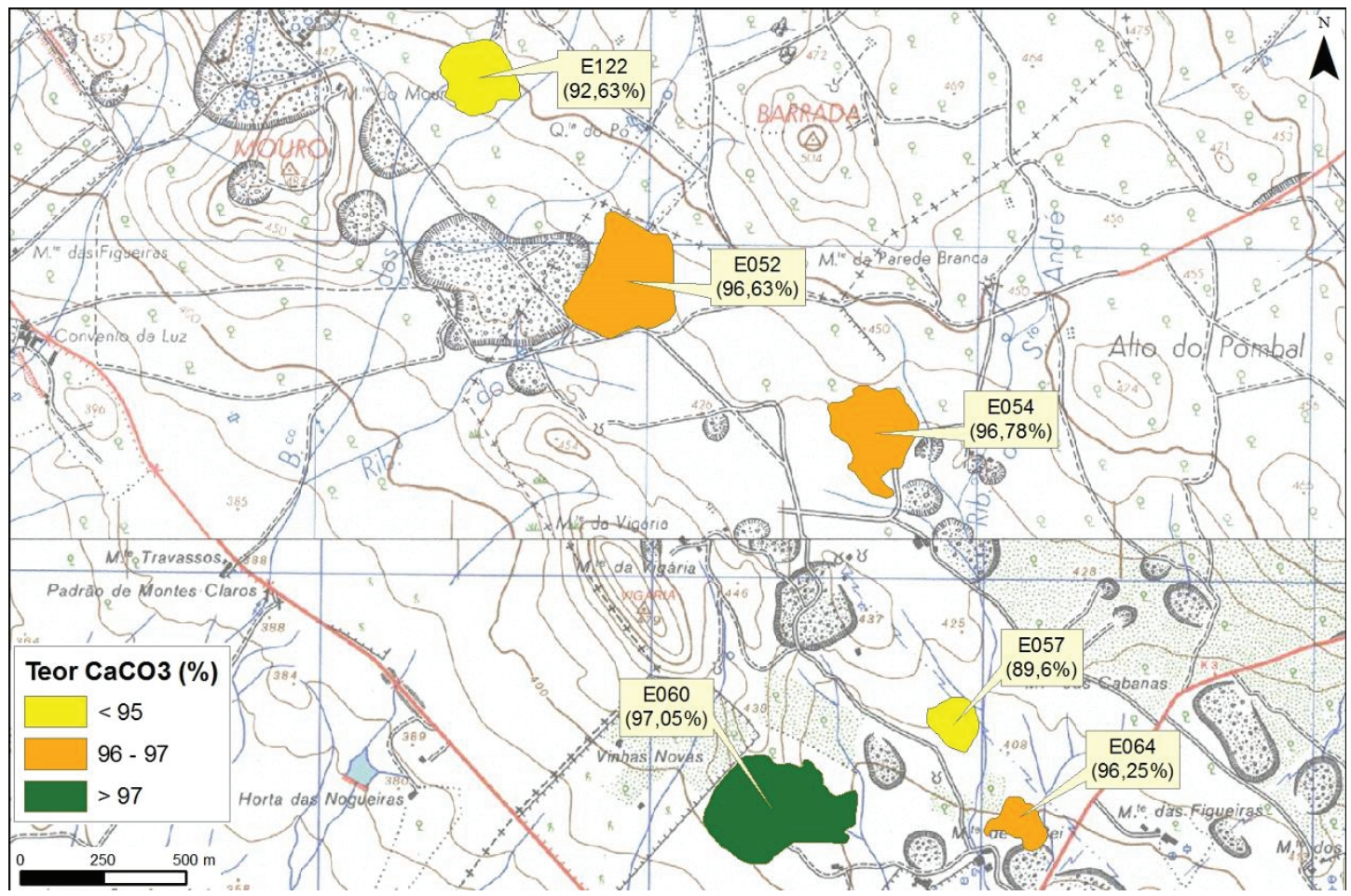

Figure 6: Calcium carbonate content for the waste rock piles from the Mouro-Vigária extraction centre.

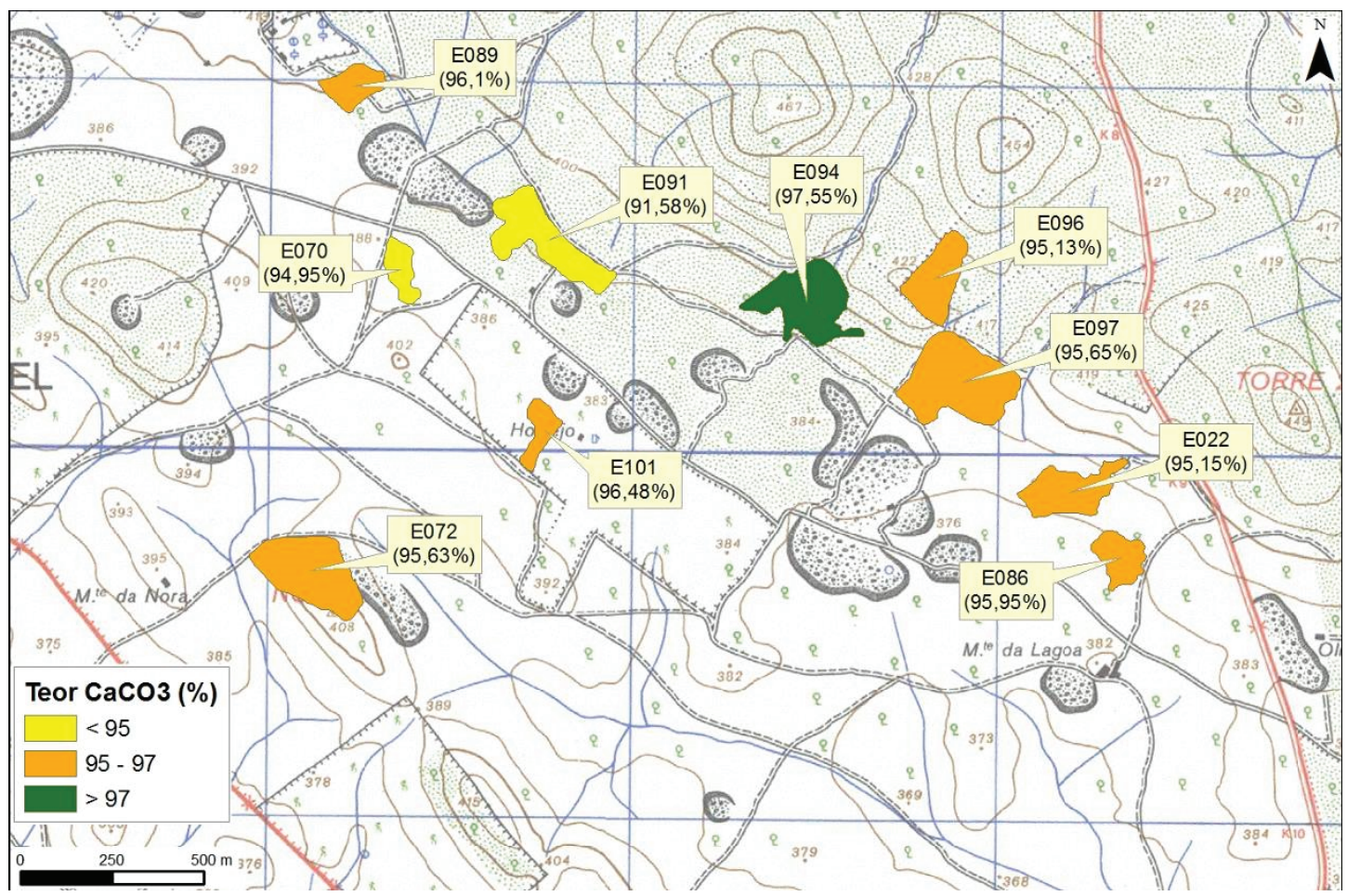

Figure 7: Calcium carbonate content for the waste rock piles from the Lagoa extraction centre. costs. 


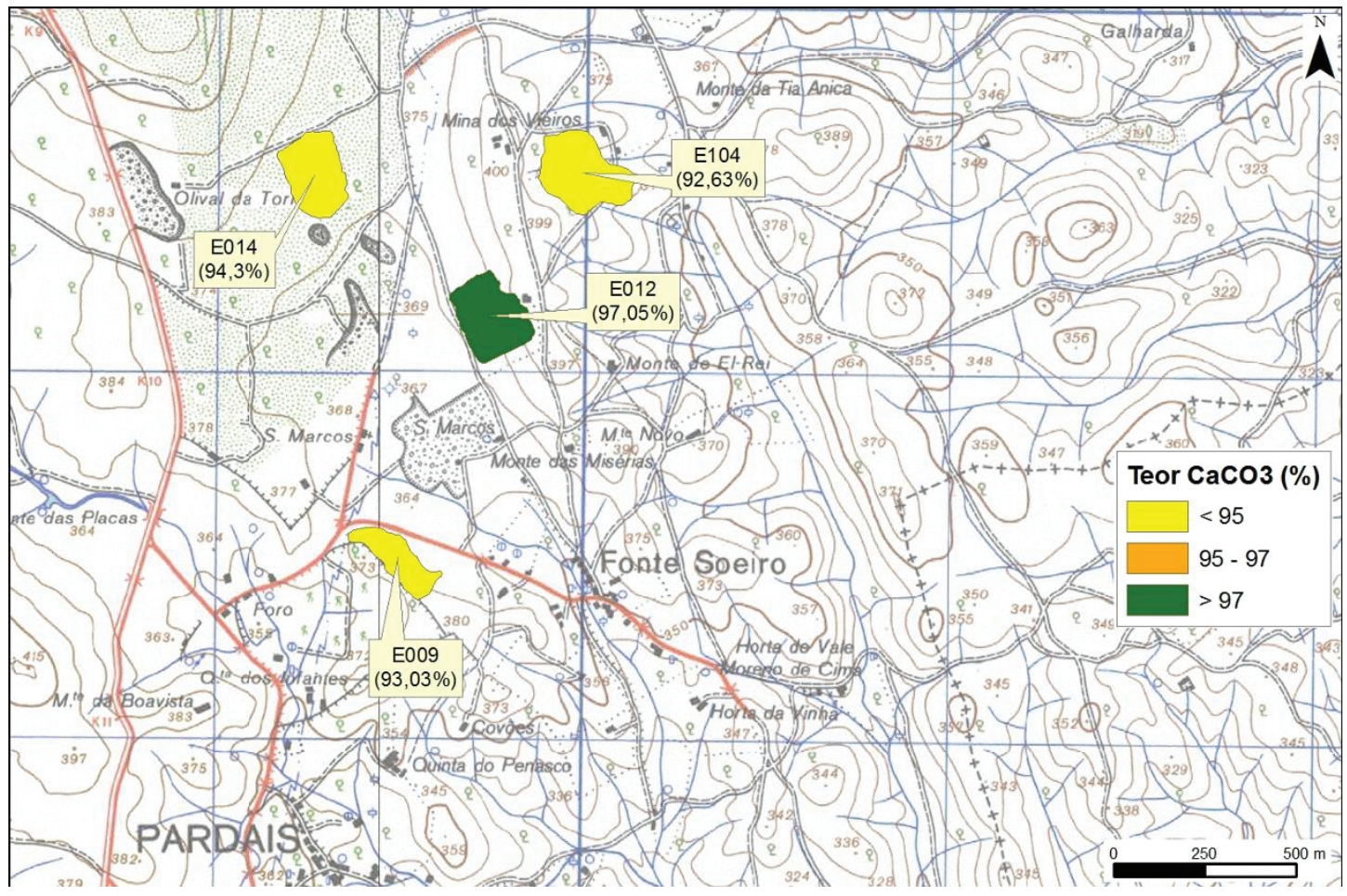

Figure 8: Calcium carbonate content for the waste rock piles from the Pardais extraction centre.

The potential use of marble waste originated from waste rock piles can also present relevant advantages to the environment, in a way that it can promote land reclamation by releasing land occupied by the piles and may help to avoid, or at least reduce, the perpetuation of land degradation by mining activities that often occur in environmentally sensitive designated areas (such as the National Parks of Aire and Candeeiros and of Arrábida).

Moreover, in relation to land planning and management plans in the exploitation areas, a few of the studied sites show conflicts with designated areas such as the REN and RAN (National Nature and Agriculture Reserves) which should be addressed in the future.

\section{Acknowledgements}

Authors acknowledge Secil/Outão for the chemical analyses performed for this study and Eng. Ângela Nunes (Secil) for her support. Partial funding of this project was provided by GeoBioTec (UIDB/04035/2020). 
TABLE 4: Obtained Global results (for the 30 samples) and grouped for each extraction centre (Cruz de Meninos, Borba, Mouro-Vigária, Lagoa and Pardais).

\begin{tabular}{|c|c|c|c|c|c|c|c|c|c|c|c|c|c|c|}
\hline & & $\mathrm{Na}_{2} \mathrm{O}$ & MgO & $\mathrm{Al}_{2} \mathbf{O}_{3}$ & $\mathrm{SiO}_{2}$ & $\mathbf{K}_{2} \mathbf{O}$ & $\mathrm{CaO}$ & $\mathrm{TiO}_{2}$ & MnO & $\mathbf{F e}_{2} \mathbf{O}_{3}$ & IR & LOI & TOC & $\mathrm{CaCO}_{3}$ \\
\hline & & (\%) & (\%) & (\%) & (\%) & (\%) & (\%) & (\%) & (\%) & (\%) & (\%) & (\%) & (\%) & (\%) \\
\hline \multirow{4}{*}{$\begin{array}{l}\text { Global } \\
\text { results }\end{array}$} & Mean & 0.03 & 0.82 & 0.41 & 1.42 & 0.12 & 55.73 & 0.02 & 0.01 & 0.25 & 2.27 & 43.57 & 0.08 & 95.26 \\
\hline & Max. & 0.08 & 1.97 & 0.82 & 2.42 & 0.23 & 58.20 & 0.11 & 0.06 & 0.40 & 4.16 & 52.82 & 0.22 & 97.55 \\
\hline & Min. & 0.00 & 0.46 & 0.26 & 0.87 & 0.00 & 43.65 & 0.00 & 0.00 & 0.11 & 1.14 & 39.75 & 0.03 & 89.60 \\
\hline & SD & 0.02 & 0.41 & 0.16 & 0.39 & 0.05 & 2.45 & 0.02 & 0.01 & 0.08 & 0.71 & 3.04 & 0.05 & 1.89 \\
\hline \multirow{2}{*}{$\begin{array}{l}\text { Cruz de } \\
\text { Meninos }\end{array}$} & Mean & 0.03 & 0.58 & 0.34 & 1.40 & 0.09 & 56.95 & 0.02 & 0.01 & 0.24 & 1.47 & 43.39 & 0.07 & 97.14 \\
\hline & SD & 0.01 & 0.04 & 0.04 & 0.26 & 0.00 & 0.69 & 0.03 & 0.01 & 0.12 & 0.23 & 1.56 & 0.03 & 0.06 \\
\hline \multirow[t]{2}{*}{ Borba } & Mean & 0.03 & 0.92 & 0.42 & 1.36 & 0.13 & 56.06 & 0.03 & 0.01 & 0.32 & 2.18 & 42.74 & 0.10 & 95.44 \\
\hline & SD & 0.03 & 0.45 & 0.14 & 0.38 & 0.08 & 0.59 & 0.02 & 0.02 & 0.05 & 0.66 & 1.89 & 0.05 & 1.27 \\
\hline \multirow{2}{*}{$\begin{array}{l}\text { Mouro- } \\
\text { Vigária }\end{array}$} & Mean & 0.02 & 0.65 & 0.39 & 1.44 & 0.11 & 54.49 & 0.02 & 0.01 & 0.22 & 2.60 & 44.81 & 0.09 & 94.82 \\
\hline & SD & 0.03 & 0.16 & 0.16 & 0.42 & 0.03 & 5.39 & 0.01 & 0.01 & 0.06 & 1.03 & 4.08 & 0.07 & 3.04 \\
\hline \multirow[t]{2}{*}{ Lagoa } & Mean & 0.03 & 0.98 & 0.43 & 1.44 & 0.13 & 55.75 & 0.02 & 0.00 & 0.22 & 2.32 & 44.38 & 0.08 & 95.42 \\
\hline & SD & 0.01 & 0.53 & 0.16 & 0.45 & 0.05 & 1.03 & 0.02 & 0.01 & 0.07 & 0.61 & 3.46 & 0.03 & 1.55 \\
\hline \multirow[t]{2}{*}{ Pardais } & Mean & 0.02 & 0.62 & 0.43 & 1.51 & 0.12 & 56.24 & 0.03 & 0.01 & 0.21 & 2.23 & 41.41 & 0.07 & 94.25 \\
\hline & SD & 0.00 & 0.12 & 0.26 & 0.44 & 0.06 & 0.91 & 0.06 & 0.02 & 0.11 & 0.46 & 1.80 & 0.03 & 2.00 \\
\hline
\end{tabular}

\section{References}

[1] Costa, C. (1992). As Pedreiras do Anticlinal de Estremoz. Ac Geologia de Engenharia na Exploração e Recuperação Ambiental de Pedreiras. PhD Thesis, FCTUNL, p. 470.

[2] Ribeiro, T. (2010). Metodologia para a caracterização das escombreiras da Zona dos Mármores (Alentejo) visando a avaliação do potencial de reutilização da matériaprima. e-Terra: Rev. Electr. de Ciências da Terra, vol. 20, issue 18, p. 4.

[3] Ribeiro, T. (2011). Valorização de escombreiras da indústria extractiva de mármores no Alentejo. MSc Thesis, FCTUNL, p.79.

[4] Moura, A. C. (1991). Rochas Ornamentais Carbonatadas de Portugal: os Mármores. Definição e Características Gerais. Bol. Minas, vol. 28, pp. 3-15.

[5] Boynton, R. S. (1980). Chemistry and Technology of Lime and Limestone. WileyInterscience; 2 ed., p. 592.

[6] Velho, J. L., Gomes, C. And Romariz, C. (1998). Minerais Industriais. Geologia, propriedades, tratamentos, aplicações, especificações, produções e mercados. Gráfica-Coimbra, p. 591. 
[7] Ellen MacArthur Foundation, (2019). Completing the Picture: How the Circular Economy Tackles Climate Change. Access: https://www.ellenmacarthurfoundation. org/assets/downloads/Completing_The_Picture_How_The_Circular_Economy_Tackles_Climate_Change_V3_26_September.pdf. 